\title{
Pelvic floor parameters in women with gynecological endocrinopathies: a systematic review
}

\author{
(iD) úlia Ferreira Fante ${ }^{1}$ \\ (D) Cristine Homsi Jorge Ferreira ${ }^{2}$ \\ (iD) Cassia Raquel Teatin Juliato ${ }^{1}$ \\ D Cristina Laguna Benetti-Pinto ${ }^{1}$ \\ (iD) Glaucia Miranda Varella Pereira' \\ (iD) Luiz Gustavo Oliveira Brito'
}

1. Department of Obstetrics and Gynecology, School of Medical Sciences, University of Campinas 2. Department of Health Sciences, Ribeirão Preto Medical School, University of São Paulo

http://dx.doi.org/10.1590/1806-9282.66.12.1742

\begin{abstract}
SUMMARY
There is no pooled information about pelvic floor parameters (muscle assessment, disorders) of women with gynecologicaL endocrinopathies (eg. polycystic ovary syndrome, congenital adrenal hyperplasia, premature ovarian insufficiency). Given that, a systematic review was performed on the Pubmed, Scopus, Google Scholar, Scielo and PEDro databases regarding the main gynecological endocrinopathies [polycystic ovary syndrome (PCOS), premature ovarian insufficiency (POI), congenital adrenal hyperplasia (CAH) and hyperprolactinemia (HPL)] since their inception to April 2020. Data quality assessment was made by the Newcastle-Ottawa Scale (NOS) adapted for cross-sectional studies. A total of 4,272 results were retrieved from all databases. After excluding duplicate results and screening by title and abstract, nine studies were selected for quantitative analysis. Seven studies were performed with women with PCOS and two studies with POI. Women with PCOS presented a higher prevalence of urinary incontinence (UI) among obese women, a higher thickness of the levator ani muscle, and higher levels of muscle activity measured by surface electromyograph when compared to the control women. Regarding POI, there was no association with UI, FI, and POP. NOS found that the quality assessment for these selected studies ranged from 5 to 8 . We concluded that higher pelvic muscle activity and volume were found in women with PCOS, with further studies needed to confirm this data. Literature was scant about POI, CAH, and HPL.
\end{abstract}

KEYWORDS: Systematic review. Urinary incontinence. Pelvic floor. Polycystic ovary syndrome. Menopause, premature.

\section{INTRODUCTION}

The female endocrine axis is complex and connects the hypothalamus, hypophysis, ovaries, and uterus ${ }^{1}$. Estrogen and progesterone are the most important hormones and any interruption on the hypothalamus-hypophysis-ovarian (HHO) axis may cause chronic anovulation or other menstrual cycle disorders, each one with its specificities ${ }^{2}$.

The female pelvic floor is composed of muscles, ligaments, and fascia that act as support for the bladder, reproductive organs, and rectum. It is related to micturition, defecation, sexual function, and has the same embryologic origin as the vulva, vagina, and inferior urinary tract ${ }^{3}$. Similarly, it presents estrogen and progesterone receptors ${ }^{4}$. Given that sexual steroids stimulate the proliferation, differentiation, and maturation of target organs and/or glands, and its

DATE OF SUBMISSION: 20-JUL-2020

DATE OF ACCEPTANCE: 25-Jul-2020

CORRESPONDING AUTHOR: Luiz Gustavo Oliveira Brito,

Rua Alexander Fleming, 101 - Cidade Universitária, Barão Geraldo, Campinas - 13083-881 - São Paulo - Brasil - Tel:: 55-19-3521-9595

E-mail: Igobrito@gmail.com 
deficit may cause a disintegration of tissue-dependent hormones, we do not know whether the hormonal variation found within some gynecological endocrinopathies may influence the inferior urinary tract or pelvic floor muscles 5 .

Some endocrinopathies are related to the reduction of hormonal levels and others, with the increase. Thus, women with premature ovarian insufficiency (POI) characterized by hypoestrogenism and increased FSH levels and women with hyperandrogenism or other endocrine diseases such as hyperprolactinemia, may present different local hormone levels, and we do not know whether this hormonal microenvironment may influence the female pelvic floor.

The higher presence of pelvic floor dysfunctions in middle-aged women is usually related to age-related modifications; however, hypoestrogenism may be related to these disorders as well. Furthermore, hyperandrogenism may activate receptors in the pelvic floor and generate different behaviors. The relationship between the PF and hormonal status is still unknown. Thus, we sought to understand if women with these disorders may present different levels of urinary, vaginal, and fecal symptoms or different pelvic muscle measurements in comparison to control women, by performing a systematic review of the literature.

\section{METHODS}

Review registration, eligibility, and inclusion/ exclusion criteria

This systematic review was submitted to registration at the PROSPERO database for systematic reviews (CRD42019128540). We included all studies, containing women with gynecological endocrinopathies (premature ovarian insufficiency, polycystic ovary syndrome, hyperprolactinemia, congenital adrenal hyperplasia), with no restriction to language and publication date. Since the term gynecological endocrinopathy is not standardized, we have chosen this group of endocrine disorders whose hormonal disbalance may play a role in women's pelvic floor. We have excluded: experimental studies, studies that analyzed general muscle groups, male subjects, and pelvic dysfunction after surgeries.

\section{Study search and selection/data extraction}

Study search was performed by two authors (J.F.F and L.G.O.B.), on the following databases: PubMed/ MEDLINE, Scopus/EMBASE, Google Scholar, SciELO, and PEDro. The last search data was July 6 2020. We used the following strategy:

- PubMed/MEDLINE - ("pelvic floor muscle" OR "pelvic floor" OR electrostimulation OR biofeedback OR incontinence OR "pelvic organ prolapse" OR prolapse) (PCOS OR "polycystic ovary syndrome" OR polycystic OR prolactin OR hyperprolactinemia OR "congenital adrenal hyperplasia" OR hirsutism OR "primary ovarian insufficiency" OR "premature ovarian failure") NOT (man OR animal);

- Scopus/EMBASE - (“"pelvic floor” OR electrostimulation OR biofeedback OR incontinence OR "pelvic organ prolapse") (pcos OR "polycystic ovary syndrome" OR "primary ovarian insufficiency" OR hyperprolactinemia OR "congenital adrenal hyperplasia"));

- Google Scholar - "primary ovarian insufficiency" "premature ovarian failure" ("pelvic floor" OR incontinence OR prolapse); "polycystic ovary syndrome" "hirsutism" ("pelvic floor" OR incontinence OR prolapse), "congenital adrenal hyperplasia" ("pelvic floor" OR incontinence OR prolapse); "hyperprolactinemia” ("pelvic floor" OR incontinence OR prolapse) - for each item, an independent search was performed.

- SciELO - (Primary Ovarian Insufficiency, Hirsutism, Polycystic Ovary Syndrome, Hyperprolactinemia, Congenital adrenal hyperplasia) - for each item, an independent search was performed in English and Portuguese languages.

-PEDro - (Primary Ovarian Insufficiency, Hirsutism, Polycystic Ovary Syndrome, Hyperprolactinemia, Congenital adrenal hyperplasia) - for each item, an independent search was performed.

\section{Outcomes}

The following variables were investigated during data extraction prior to study selection: urinary incontinence, pelvic organ prolapse or fecal incontinence by self-report or measured by specific questionnaire; voiding or other irritative symptoms (urinary frequency, nocturia, bladder or pelvic pain) by self-report or measured by specific questionnaire; pelvic floor muscle assessment (strength, tone, thickness, maximum voluntary contraction - MVC) by PERFECT and Oxford modified scales, vaginal manometer (Peritron $^{\mathrm{TM}}$ ), surface electromyography (sEMG) and transperineal ultrasound.

\section{Quality assessment}

We used the Newcastle-Ottawa Scale adapted for cross-sectional studies. This tool was initially 
developed to assess the quality of observational studies and contains eight items divided into three domains (selection, comparability, and outcome). The score was divided into good quality (3-5 points for selection, 1-2 points for comparability, and 2-3 for outcomes), moderate quality (2 points for selection, 1-2 for comparability, and 2-3 for outcomes), and poor quality (0-1 points for selection, 0 for comparability and $0-1$ for outcomes) $)^{6,7}$.

\section{RESULTS}

Characteristics of the selected studies and NOS quality assessment

Figure 1 depicts the retrieved results and details for excluding studies for each step of the analysis. A total of 4,272 studies were found. After excluding the duplicates and studies that did not match the title and/or abstract, and studies with no eligibility criteria, only 14 studies were potentially eligible for final analysis. Nine manuscripts were included for quantitative analysis. It was not possible to perform a metanalysis due to the heterogeneity of the instruments used to assess outcomes among the studies. All of them had a cross-sectional design ${ }^{8-16}$, and most of them were performed in Brasil $(n=6)$, followed by China, Iran, and Turkey $(\mathrm{n}=1)$, comprising 1,132 women. Four of them ${ }^{9,11,12,15}$ did not inform the study period, and five presented a variation of 4 to 24 months of data collection (Table 1). Seven studies addressed polycystic ovary syndrome and two analyzed premature ovarian insufficiency. We did not find any studies investigating hyperprolactinemia or congenital adrenal hyperplasia. Regarding the primary outcomes (pelvic floor disorders), we did not find any studies connecting PCOS directly with urinary incontinence, fecal incontinence, or pelvic organ prolapse. One study within POI women ${ }^{16}$ focused on PFDs. Basically, our secondary outcomes were the main results of this review.
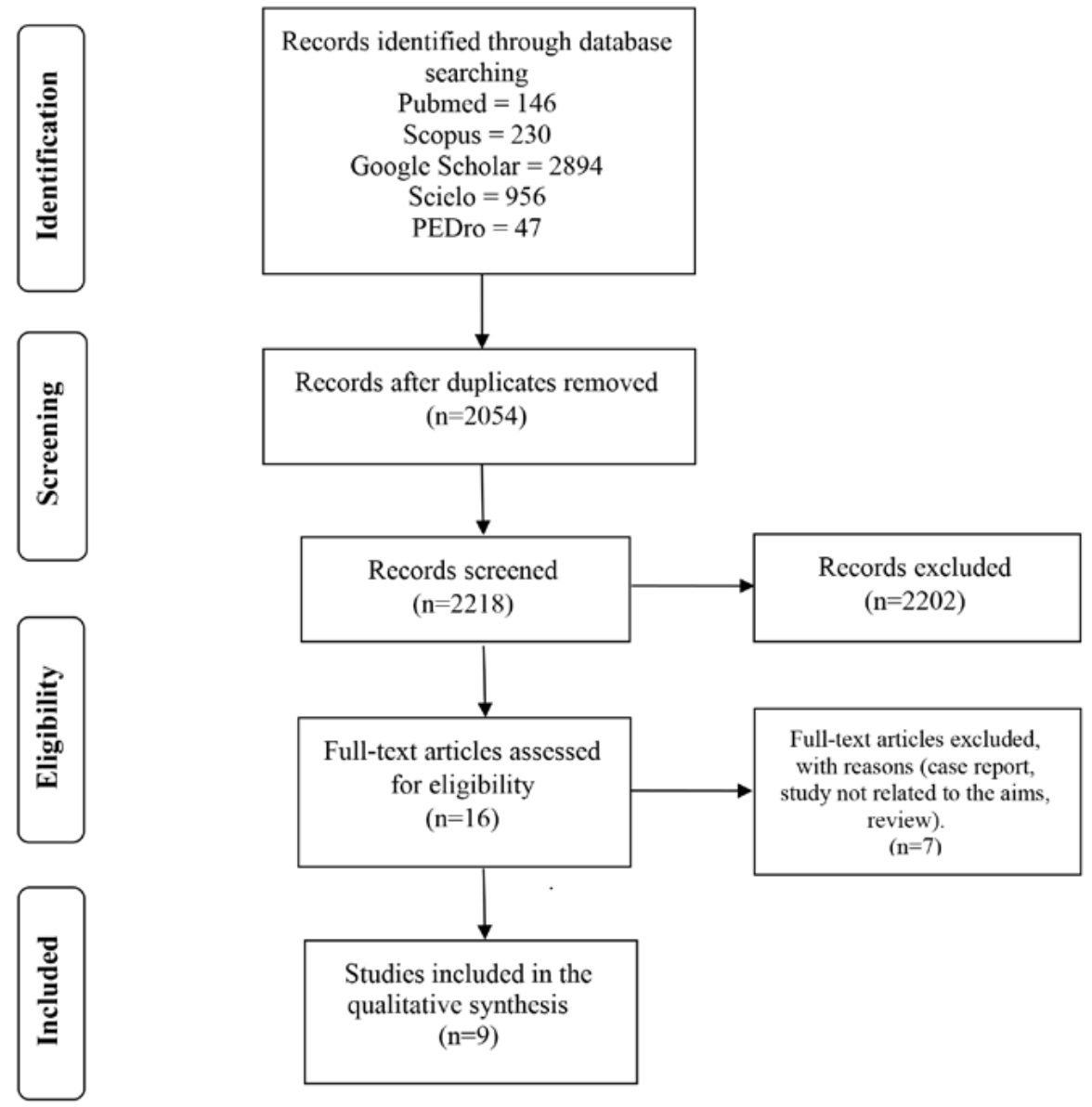

FIGURE 1. PRISMA FLOWCHART FOR STUDY SELECTION. 
Regarding the NOS for quality assessment, half of the studies $(n=4)$ presented scores equal to six (good quality) , 11,12,14. Three studies $^{8,13,15}$ scored five (good quality), one study ${ }^{3}$ scored seven, and one ${ }^{16}$ scored eight (Table 2). None of the studies presented an analysis of the non-responders since no studies were surveys or cohort databases; thus, they lacked this item within the selection domain.

Diverse instruments were applied to these studies. Most commonly, the questionnaires were self-administered and created by the authors: International Consultation on Incontinence Questionnaire-Urinary Incontinence Short Form (ICIQ-UI-SF), Short Form Health Survey 36 (SF-36) Pelvic Floor Disability Index 20 (PFDI-20), Pelvic pain and urgency/frequency questionnaire (PUFq). Other instruments were the transperineal 3D ultrasound (US), surface electromyography (EMG), and manometer (Table 2).

\section{Premature ovarian insufficiency}

We found two studies ${ }^{8,16}$ that sought to investigate the association between POI and SUI. One ${ }^{8}$ was performed in China, with 149 women with POI treated with hormone therapy (HT) and 303 women from the control group, matched by age, BMI, and parity. The main objective was to investigate the prevalence of urinary incontinence within this population, as well as to assess the effects of the temporal, individual, and therapeutic factors on SUI for POI women. They had a higher SUI prevalence (20.9\%) than the control group $(16.2 \%)$, with no statistically significant difference $(\mathrm{p}=0.297)$. The duration of POI and HT use did not have any effect on the incidence of SUI. The risk factors that were associated with SUI in POI women were: age over 40 years $(\mathrm{p}=0.001)$, primiparity $(\mathrm{p}=0.001)$, and vaginal delivery $(\mathrm{p}=0.023)$.

The other study ${ }^{16}$ was performed in Brasil, and 150

TABLE 1. GENERAL CHARACTERISTICS OF THE SELECTED STUDIES.

\begin{tabular}{|c|c|c|c|c|c|c|}
\hline References & $\begin{array}{l}\text { Study De- } \\
\text { sign/Period }\end{array}$ & Country & $\begin{array}{l}\text { Female } \\
\text { related } \\
\text { endocr- } \\
\text { inopathy }\end{array}$ & $\begin{array}{l}\text { Sample } \\
\text { Case }+ \\
\text { control }\end{array}$ & $\begin{array}{l}\text { Mean age } \pm S D \\
\text { Case/Control }\end{array}$ & Objectives \\
\hline $\begin{array}{l}\text { Fante et al. }{ }^{\mathbf{1 6}}, \\
2020\end{array}$ & $\begin{array}{l}\text { CS/Aug- } \\
2017 / \text { Nov } \\
2018\end{array}$ & Brasil & $\mathrm{POI}$ & $150 / 150$ & $35.41 \pm 8.58 / 33.19 \pm 8.47$ & $\begin{array}{l}\text { To investigate the prevalence of self-re- } \\
\text { ported UI, POP, and FI and its associated } \\
\text { factors within POI women and a control } \\
\text { group }\end{array}$ \\
\hline Tan et al. ${ }^{\mathbf{8}}, 2018$ & $\begin{array}{l}\text { CS/ Jan } \\
2016-\text { Aug } \\
2017\end{array}$ & China & POI & 451 & $33.56 \pm 5.49 / 33.06 \pm 5.06$ & $\begin{array}{l}\text { To investigate the prevalence of SUI in } \\
\text { patients with POI and evaluate the effect } \\
\text { of temporal, individual, and therapeutic } \\
\text { factors on SUI in patients with POI. }\end{array}$ \\
\hline Melo et al. ${ }^{9}, 2018$ & $\mathrm{CS} / \mathrm{NI}$ & Brasil & PCOS & 20 & $25.3 \pm 4.5 / 26.2 \pm 4.0$ & $\begin{array}{l}\text { To assess pelvic floor muscle thickness } \\
\text { using ultrasound imaging in women with } \\
\text { PCOS and compare it to those with a } \\
\text { normal menstrual cycle. }\end{array}$ \\
\hline $\begin{array}{l}\text { Taghavi et al. }{ }^{\mathbf{1 0}} \text {, } \\
2017\end{array}$ & $\begin{array}{l}\text { CS/ } \\
\text { May-Sep- } \\
\text { tember } 2014\end{array}$ & Iran & PCOS & 202 & $28.76 \pm 5.33 / 28.48 \pm 4.87$ & $\begin{array}{l}\text { (a) To compare the prevalence of PFD } \\
\text { in patients with and without PCOS; } \\
\text { and (b) to test the hypothesis that PFD } \\
\text { varies according to the different PCOS } \\
\text { phenotypes. }\end{array}$ \\
\hline $\begin{array}{l}\text { Micussi et al. }{ }^{12} \text {, } \\
2016\end{array}$ & $\mathrm{CS} / \mathrm{NI}$ & Brasil & PCOS & 55 & $25.3 \pm 4.5 / 26.2 \pm 4.0$ & $\begin{array}{l}\text { To compare the electrical activity of PFM } \\
\text { in a group of women with PCOS and pre- } \\
\text { menopausal women during the follicular } \\
\text { phase of the normal menstrual cycle. }\end{array}$ \\
\hline $\begin{array}{l}\text { Vassimon et al. }{ }^{\mathbf{1 3}}, \\
2016\end{array}$ & $\begin{array}{l}\text { CS and } \\
\text { CC/2008- } \\
2010\end{array}$ & Brasil & PCOS & 72 & $27 \pm 5.5 / 30 \pm 4.9$ & $\begin{array}{l}\text { To assess PFM thickness and neuromus- } \\
\text { cular activity among hyperandrogenic } \\
\text { women with PCOS and controls. }\end{array}$ \\
\hline $\begin{array}{l}\text { Antônio et al. }{ }^{\mathbf{1 4}} \text {, } \\
2013\end{array}$ & $\begin{array}{l}\text { CS and } \\
\text { CC/2008- } \\
2010\end{array}$ & Brasil & PCOS & 79 & $27.2 \pm 5.5 / 37 \pm 5.3$ & $\begin{array}{l}\text { To assess PFM strength and UI among } \\
\text { hyperandrogenic women with PCOS and } \\
\text { a control group for comparison. }\end{array}$ \\
\hline $\begin{array}{l}\text { Montezuma et } \\
\text { al. }{ }^{\mathbf{1 5}}, 2011\end{array}$ & $\begin{array}{l}\text { CS con- } \\
\text { trolled/NI }\end{array}$ & Brasil & PCOS & 113 & $\begin{array}{l}24.78 \text { and } 28.75 / 31.69 \\
\text { and } 30.61\end{array}$ & $\begin{array}{l}\text { To compare reports of urine leakage and } \\
\text { quality of life between women with and } \\
\text { without polycystic ovary syndrome. }\end{array}$ \\
\hline $\begin{array}{l}\text { Sahinkanat et } \\
\text { al." }, 2011\end{array}$ & $\mathrm{CS} / \mathrm{NI}$ & Turkey & PCOS & 140 & $26.1 \pm 5.2$ & $\begin{array}{l}\text { To examine the relationship between } \\
\text { bladder symptoms and serum testos- } \\
\text { terone levels in women with polycystic } \\
\text { ovary syndrome. }\end{array}$ \\
\hline
\end{tabular}

Abbreviations: CS (cross-sectional); NI (not informed); POI (premature ovarian insufficiency); PCOS (polycystic ovary syndrome); SUI (stress urinary incontinence); PFD (pelvic floor dysfunction); PFM (pelvic floor muscle). 
TABLE 2. METHODOLOGICAL QUALITY (NEWCASTLE-OTTAWA SCALE), INDEPENDENT VARIABLE(S), INSTRUMENTS, AND THE MAIN RESULTS OF SELECTED STUDIES.

\begin{tabular}{|c|c|c|c|c|}
\hline References & Quality(NOS) & Variables & Instruments & Results \\
\hline Fante et al. ${ }^{16}, 2020$ & $\begin{array}{l}\text { Selection: } * * * * \\
\text { Comparability: } * \\
\text { Outcome: } * *\end{array}$ & $\begin{array}{l}\text { PFD (IU, POP, FI) } \\
\text { and PFM assess- } \\
\text { ment (PERFECT } \\
\text { scale) }\end{array}$ & $\begin{array}{l}\text { Self-reported } \\
\text { UI, POP, and FI } \\
\text { symptoms } \\
\text { PFDI-2O } \\
\text { KHQ }\end{array}$ & $\begin{array}{l}\text { The prevalence of self-reported UI was } 27.33 \% \text { and } \\
37.33 \% \text { for, respectively, POI and control women, with no } \\
\text { statistically significant differences. Similarly, no differ- } \\
\text { ences were perceived between the groups with regard to } \\
\text { POP and FI prevalence. The PERFECT scale presented } \\
\text { similar scores on power, endurance, repetitions, and fast } \\
\text { contractions between POI and control groups. }\end{array}$ \\
\hline Tan et al. ${ }^{\mathbf{8}}, 2018$ & $\begin{array}{l}\text { Selection: } * * \\
\text { Comparability: } * \\
\text { Outcome: } * *\end{array}$ & SUI & $\begin{array}{l}\text { Self-adminis- } \\
\text { tered question- } \\
\text { naire }\end{array}$ & $\begin{array}{l}\text { The prevalence of SUI in the POI group tended to be } \\
\text { higher than that in the control group }(20.9 \%, 30 / 149 \text { vs. } \\
16.2 \%, 49 / 303) \text {, although not significantly }(p=0.297) \text {. } \\
\text { About } 41.6 \%(62 / 149) \text { of patients with POI received HT. } \\
\text { Patients with POI and SUI were older }(p=0.018) \text { and had } \\
\text { higher BMI ( } p=0.007) \text { than women with POI without } \\
\text { SUI }(p=0.007) \text {. }\end{array}$ \\
\hline Melo et al. ${ }^{9}, 2018$ & $\begin{array}{l}\text { Selection: } * * * \\
\text { Comparability: } * \\
\text { Outcome: } * *\end{array}$ & $\begin{array}{l}\text { Pelvic Floor thick- } \\
\text { ness }\end{array}$ & $\begin{array}{l}\text { Transperineal 3D } \\
\text { ultrasound }\end{array}$ & $\begin{array}{l}\text { There was no difference between the thickness of the } \\
\text { pelvic floor muscles (PCOS group: right } 1.12 \pm 0.5 \text {, left } 1.0 \\
\pm 0.6 \text { and control group: right } 0.89 \pm 0.6 \text { and left } 0.94 \pm \\
\text { 0.4). However, the PCOS group exhibited a tendency to } \\
\text { a greater thickness. This may be due to the state of hyper- } \\
\text { androgenism or abdominal overload. }\end{array}$ \\
\hline Taghavi et al. ${ }^{\mathbf{1 0}}, 2017$ & $\begin{array}{l}\text { Selection: } * * * * \\
\text { Comparability: } * \\
\text { Outcome: } * *\end{array}$ & PFD (UI, POP, FI)) & PFDI-20 & $\begin{array}{l}\text { Briefly, the reported pelvic organ prolapse (POP) symp- } \\
\text { toms were higher in the PCOS group ( } p=0.05) \text {. The mean } \\
\text { PFD score in the HA+M+PCO group was higher com- } \\
\text { pared to other phenotypes, although the difference did } \\
\text { not reach a significant level ( } p>0.05) \text {. However, there was } \\
\text { a significant positive correlation between the luteinizing } \\
\text { hormone }(\mathrm{LH}) \text { level and the POP symptom portion of the } \\
\text { PFDI-2O }(p<0.05) \text {. }\end{array}$ \\
\hline Micussi et al. ${ }^{12}, 2016$ & $\begin{array}{l}\text { Selection: } * * * \\
\text { Comparability: } * \\
\text { Outcome: } * *\end{array}$ & $\begin{array}{l}\text { Electrical activity of } \\
\text { PFM }\end{array}$ & sEMG & $\begin{array}{l}\text { There was a difference in muscle tone }(P C O S=59.9 \\
\mathrm{mV} \text { and Control group }=25.5 \mathrm{mV} ; \mathrm{p}<0.0001) \text { and } \mathrm{MVC} \\
(\mathrm{PCOS}=159.7 \mathrm{mV} \text { and Control group }=63.7 \mathrm{mV} ; \mathrm{p}<0.0002) \\
\text { between the groups. The concentration of estradiol and } \\
\text { testosterone showed a strong correlation with tone }(r=0.9 \text {, } \\
r=0.8 \text {, respectively) and } \mathrm{MVC}(r=0.9, r=0.9 \text { respectively) in } \\
\text { women with PCOS. }\end{array}$ \\
\hline $\begin{array}{l}\text { Vassimon et al. }{ }^{13} \text {, } \\
2016\end{array}$ & $\begin{array}{l}\text { Selection: } * * \\
\text { Comparability: } * \\
\text { Outcome: } * *\end{array}$ & $\begin{array}{l}\text { PFM (electrical } \\
\text { activity and pelvic } \\
\text { floor thickness) }\end{array}$ & sEMG/US & $\begin{array}{l}\text { There were no significant differences in PFM sEMG activ- } \\
\text { ity between PCOS and controls in any of the contractions: } \\
\text { quick contraction ( } 73.23 \mathrm{mV} / 71.56 \mathrm{mV} ; \mathrm{p}=0.62), 8 \mathrm{~s}(55.77 \\
\mathrm{mV} / 54.17 \mathrm{mV} ; \mathrm{p}=0.74) \text {, and } 60 \mathrm{~s}(49.26 \mathrm{mV} / 47.32 \mathrm{mV} \text {; } \\
\mathrm{p}=0.68) \text {, respectively. There was no difference in PFM } \\
\text { thickness during contractions evaluated by US between } \\
\text { PCOS and controls }(12.78 \mathrm{~mm} / 13.43 \mathrm{~mm} ; \mathrm{p}=0.48) \text {. }\end{array}$ \\
\hline $\begin{array}{l}\text { Antônio et al. }{ }^{\mathbf{1 4}} \\
2013\end{array}$ & $\begin{array}{l}\text { Selection: } * * * \\
\text { Comparability: } * \\
\text { Outcome: } * *\end{array}$ & $\begin{array}{l}\text { PFM strength and } \\
\text { UI }\end{array}$ & $\begin{array}{l}\text { Manometer } \\
\text { Peritron; ICIQ- } \\
\text { UI-SF }\end{array}$ & $\begin{array}{l}\text { There was no statistically significant difference in mean } \\
\text { PFM strength between the PCOS and the control group: } \\
2.7 \mathrm{~cm} \mathrm{H} 2 \mathrm{O}(95 \% \mathrm{Cl}-6.2-11.6) \mathrm{p}=0.55 \text {. The prevalence of } \\
\text { UI was } 18.6 \% \text { in the control group compared with } 0 \% \text { in } \\
\text { the PCOS group } \mathrm{p}<0.01 \text {. }\end{array}$ \\
\hline $\begin{array}{l}\text { Montezuma et al. }{ }^{\mathbf{1 5}} \text {, } \\
2011\end{array}$ & $\begin{array}{l}\text { Selection: } * * * \\
\text { Comparability: } * \\
\text { Outcome: } *\end{array}$ & Ul symptoms & ICIQ-SF, SF-36 & $\begin{array}{l}\text { The answers to the ICIQ-SF revealed a significant } \\
\text { difference in urinary function between the groups, with } \\
24 \% \text { of the subjects in the control group with BMI > } \\
\text { reporting urinary incontinence. The mean scores for the } \\
\text { SF-36 questionnaire revealed that group II had the lowest } \\
\text { quality of life. }\end{array}$ \\
\hline $\begin{array}{l}\text { Sahinkanat et al."11, } \\
2011\end{array}$ & $\begin{array}{l}\text { Selection: } * * * \\
\text { Comparability: } * \\
\text { Outcome: } * *\end{array}$ & $\begin{array}{l}\text { Bladder storage } \\
\text { symptoms }\end{array}$ & PUFq & $\begin{array}{l}\text { A significant positive correlation was found between } \\
\text { serum testosterone level and total, symptom and bother } \\
\text { scores of the PUFq, symptoms of dyspareunia, urgency, } \\
\text { nocturia, and bladder/pelvic pain. There was no correla- } \\
\text { tion between the serum testosterone level and ultraso- } \\
\text { nographic findings such as bladder capacity, postvoid } \\
\text { residual volume, and symptom of frequency. }\end{array}$ \\
\hline
\end{tabular}

Abbreviations: POI (premature ovarian insufficiency); PCOS (polycystic ovary syndrome); SUI (stress urinary incontinence); PFD (pelvic floor dysfunction); PFM (pelvic floor muscle); UI (urinary incontinence); PFDI-2O (pelvic floor distress inventory-20); $E$ EMG (surface electromyography); PUFq (pelvic pain and urgency/frequency questionnaire); US (ultrasound); SF-36 (Short-Form Health Survery); ICIQ-SF (international consultation on incontinence questionnaire-short form); ICIQ-UI-SF (international consultation questionnaire - urinary incontinence short form; NOS (Newcastle-Ottawa scale); KHQ (Kings Health Questionnaire) 
patients with POI were control-matched for age and body weight $(\mathrm{n}=150)$. There was no difference between the groups with regard to self-reported UI, POP, and FI ( $>$.05). Moreover, pelvic floor muscle assessment by the PERFECT scale did not differ between the groups.

\section{Polycystic ovary syndrome (PCOS)}

Seven studies were retrieved ${ }^{9-15}$. Five of them aimed to assess the relationship between hyperandrogenism and some variables about muscle activity (tone, strength, neuromuscular activity, and thickness) and urinary symptoms. The other two studies aimed to investigate or compare the prevalence of pelvic floor dysfunctions between women with and without PCOS.

Montezuma et al..$^{15}$ investigated the prevalence of urinary incontinence (UI) and quality of life within obese and non-obese women with and without PCOS, and found a higher UI prevalence in overweight women of the control group (24\%) with a statistical difference among the groups ( $\mathrm{p}=0.04)$; however, when the groups were stratified by BMI, no difference was noted. Furthermore, there was no difference regarding urine loss among the groups, and the quality of life was lower in overweight PCOS women. Taghavi et al. ${ }^{10}$ assessed the prevalence of pelvic floor dysfunctions in patients with and without PCOS according to the clinical phenotypes (menstrual disorders/hirsutism) and found that PCOS women presented more pelvic prolapse symptoms $(\mathrm{p}=0.05)$. Also, women with menstrual disorders and hirsutism presented higher scores for pelvic floor dysfunctions when compared with each phenotype occurring individually, but with no statistical difference ( $p>0.05)$.

Regarding pelvic floor muscle within PCOS women, studies were not confluent with their findings. One study did not confirm its hypothesis that PCOS women with hyperandrogenism would generate higher muscle strength in PFM with control women ${ }^{14}$. Vassimon et al. ${ }^{13}$ did not find any significant difference between PCOS and control women regarding fast $(p=0.62)$ and sustained pelvic muscle contractions $(\mathrm{p}=0.74)$ measured by surface electromyography. Perineal muscle thickness was not different between the groups during contractions when measured by ultrasound $(p=0.48)$. Another study specifically measured the levator ani muscle, and the PCOS group presented a higher muscle thickness when compared to the control group (PCOS right side: $1.2 \pm 0.5 \mathrm{~cm}$; PCOS left side: $1.8 \pm 0.6 \mathrm{~cm}$ vs Control right side: $0.89 \pm 0.6 \mathrm{~cm}$; Control left side: $0.94 \pm 0.4 \mathrm{~cm}$ ), with no significant difference between the groups ${ }^{9}$.
One study ${ }^{11}$ analyzed the association between testosterone levels and bladder symptoms by using the Pelvic pain and urgency/frequency (PUFq) questionnaire, and they found a positive correlation between testosterone levels with total PUFq score $(p=0.000)$, symptoms $(p=0.000)$, bother $(p=0.000)$, nocturia $(p=0.008)$, dyspareunia $(p=0.000)$, pain frequency $(p=0.024)$, urgency $(p=0.006)$, pain severity $(p=0.016)$, and urgency severity $(\mathrm{p}=0.000)$; however, there was no correlation between testosterone and ultrasonographic findings related to bladder capacity $(p=0.345)$ and postvoiding residue $(\mathrm{p}=0.061)$.

Finally, Micussi et al. ${ }^{12}$ found significant differences between PCOS and control groups with regard to obesity when analyzing the electrical activity by surface electromyography; PCOS patients presented higher activity with or without obesity (obese PCOS $-69.3 \mu \mathrm{V}$ versus control $-25.5 \mu \mathrm{V}$; overweight PCOS $-54.6 \mu \mathrm{V}$ versus control - $25.5 \mu \mathrm{V}$; non-obese PCOS $47.7 \mu \mathrm{V}$ versus control $-25.5 \mu \mathrm{V})$. Furthermore, PCOS women presented higher maximum contraction volumes versus the control group (obese PCOS - 202.8 $\mu \mathrm{V}$ versus control $-63.7 \mu \mathrm{V}$; overweight PCOS -140.9 $\mu \mathrm{V}$ versus control $-63.7 \mu \mathrm{V})$.

\section{DISCUSSION}

This review has found nine studies addressing pelvic floor parameters in gynecological endocrinopathies. Two of these studies analyzed PFDs and POI, and the other seven investigated PFDs with PCOS. It seems that the connection between the pelvic floor and female related endocrinopathies is not so well investigated. Estrogen receptors are present in the genital area and within the urinary tract. They are also related to the increase of collagen synthesis within connective tissue from the pelvic floor ${ }^{17}$, as well as muscle regenerative markers ${ }^{18}$. Thus, hypoestrogenism will have effects within these areas, with vulvovaginal and urinary symptoms ${ }^{19}$. However, we cannot ascertain whether estrogen, by itself, is responsible for all these symptoms or plays a main role in pelvic floor dysfunctions.

Primary ovarian insufficiency is an important topic that needs further studies. Two studies were found, and we did not find any association with $\mathrm{UI}^{8,16}$. However, one of the studies ${ }^{8}$ observed that even with no statistically significant difference, POI women presented higher UI prevalence than control women. Women with POI, especially patients that did not 
have the chance to start hormone therapy and present a longer POI duration, represent a good model to understand whether hypoestrogenism may cause pelvic floor dysfunction. The other study had a smaller group of patients with POI not using HT and the reason for that is because these patients were the ones who were in their first consultations ready to start using it. It would be unethical not to prescribe HT for these women just to see the effect of hypoestrogenism on PFM function and the incidence of PF disorders.

Tan et al. ${ }^{8}$ did not find any significant differences between HT usage by POI women and the presence of SUI. Furthermore, the association between HT usage and urinary continence has not yet been established, and according to some data, oral HT impairs urinary symptoms ${ }^{20}$. Some authors have found that estrogen improves collagen production ${ }^{17}$, whereas others suggest that exogenous estrogen may be related to collagen degradation in the bladder neck region, altering bladder support and favoring symptoms related to SUI. It was observed that women with SUI presented a decrease of collagen production and that its degradation was augmented after six months of using $\mathrm{HT}^{21}$; there is a lack of evidence about whether the role of HT on POI women and PFDs would be general. There is a case report from a 25-year nulliparous patient, with the diagnosis of POI presenting constipation and localized scleroderma with an advanced uterine prolapse; this patient sheds some light about the etiology of hypoestrogenism associated with other factors that increase intra-abdominal pressure (eg. constipation) causing POP22.

Another relationship that should be explored is between androgens and the pelvic floor. Skeletal muscles present receptors for estrogens and androgens, and it is believed that the variation of these hormones affects endurance and muscular strength ${ }^{23}$. As androgens may increase muscle mass, this might happen with PCOS women with clinical and/or laboratorial hyperandrogenism ${ }^{24-26}$. Some studies, despite not presenting significant differences among the groups, show that the presence of circulating androgens may generate more muscle thickness ${ }^{9}$ and strength $^{14}$. On the other hand, PCOS women may present a worse quality of life, more prolapse, and urinary symptoms ${ }^{10,11,15}$. Central obesity caused by PCOS may increase bladder pressure and urethral mobility, contributing to urinary incontinence ${ }^{27}$. However, Micussi et al..$^{12}$, have found that hyperandrogenism in PCOS women may be a protective factor for the pelvic floor since women with high BMI presented better muscle electric activity. This information may be related to high levels of estrogen and testosterone in the PCOS group. There is evidence that estradiol regulates the growth and regeneration of the skeletal muscle fibers through satellite cells and modulates immune responses ${ }^{17}$. Testosterone stimulates protein synthesis, recruits satellite cells by the anabolic effect, and inhibits protein degradation, increasing muscle fiber recruitment ${ }^{28}$. Regarding PCOS studies, obesity seems to play a role in a more meaningful way than the endocrinopathy itself.

No studies were found with regard to hyperprolactinemia or congenital adrenal hyperplasia. As we know that high levels of prolactin, in a chronic fashion, may decrease muscle mass in non-treated patients, studies analyzing the pelvic floor of patients with this disorder would be interesting to see its effect.

The strengths of this review were the fact that, to our knowledge, there is no previous compilation of the literature looking for women with gynecological endocrinopathies that could influence pelvic floor muscles and other structures and the development of these disorders. The limitations were related to the scant number of retrieved results, and since these studies are cross-sectional, it is not possible to infer a causality relationship. Other factors are certainly influencing this connection. The quality assessment for these studies showed moderate to good quality. We did not use a filter to exclude studies with low quality, but this did not impact the number of retrieved results.

Further studies with diseases such as premature ovarian insufficiency are needed so that we may have a deeper understanding of how estrogen (and its absence) impact the pelvic floor. Similarly, androgen seems to play a role in increasing muscle strength and thickness. However, PFM anatomy differs from PFM function, and this should be the goal for future studies.

Funding: Coordenação de Aperfeiçoamento de Pessoal Nível Superior (CAPES), code 001

\section{Author's Contribution}

J.F. Fante: data curation, investigation, methodology, project management, writing of the original draft, review, editing; L.G. Brito: conceptualization, methodology, project management, supervision, review, editing; C.H. Ferreira: formal analysis, visualization; C.R. Juliato: formal analysis, supervision, visualization; C.L. Benetti-Pinto: formal analysis, visualization, review, editing; G.M. Pereira: methodology, visualization. 


\section{RESUMO}

Existe informação não organizada sobre a avaliação do assoalho pélvico de mulheres com endocrinopatias ginecológicas (ex. síndrome dos ovários policísticos - SOP, hiperplasia adrenal congênita - HAC, insuficiência ovariana prematura - IOP). Dessa forma, objetivamos realizar uma revisão sistemática foi realizada nas bases Pubmed, Scopus, Google Scholar, Scielo e PEDro sobre as endocrinopatias ginecológicas (SOP, HAC, IOP e hiperprolactinemia (HPL) desde a origem a abril de 2020. A avaliação da qualidade de dados foi realizada pela escala de Newcastle-Ottawa Scale (NOS) adaptada para estudos transversais. De 4,272 resultados encontrados em todas as databases, após exclusão por duplicatas, triando por título e resumos, nove estudos foram selecionados para análise quantitativa. Sete estudos foram realizados para mulheres com SOP e dois estudos com IOP. Em suma, mulheres com SOP apresentados uma alta prevalência de incontinência urinária (IU) em mulheres obesas, alta espessura do músculo elevador do ânus, altos níveis de atividade muscular aferida por eletromiografia de superfície quando comparadas com mulheres do grupo controle. Sobre a IOP, esta não foi associada com IU, IF e POP. A escala NOS evidenciou que a qualidade dos estudos selecionados variou de 5 a 8 . Concluímos que uma alta atividade e volume muscular foi encontrada em mulheres com SOP, com estudos posteriores sendo necessários para confirmar estes achados. Literatura foi escassa para IOP, HAC e HPL.

PALAVRAS-CHAVE: Revisão sistemática. Incontinência urinária. Diafragma da pelve. Síndrome do ovário policístico. Menopausa precoce.

\section{REFERENCES}

1. Barbieri RL. The endocrinology of the menstrual cycle. Methods Mol Biol. 2014;1154:145-69.

2. Popat VB, Prodanov T, Calis KA, Nelson LM. The menstrual cycle: a biological marker of general health in adolescents. Ann N Y Acad Sci. 2008;1135:43-51.

3. Eickmeyer SM. Anatomy and physiology of the pelvic floor. Phys Med Rehabil Clin N Am. 2017;28(3):455-60.

4. Batra SC, losif CS. Progesterone receptors in the female lower urinary tract. J Urol. 1987;138(5):1301-4.

5. Copas P, Bukovsky A, Asbury B, Elder RF, Caudle MR. Estrogen, progesterone, and androgen receptor expression in levator ani muscle and fascia. J Womens Health Gend Based Med. 2001;10(8):785-95.

6. Herzog R, Álvarez-Pasquin MJ, Díaz C, Del Barrio JL, Estrada JM, Gil Á. Are healthcare workers' intentions to vaccinate related to their knowledge, beliefs and attitudes? A systematic review. BMC Public Health. 2013;13:154.

7. Stang A. Critical evaluation of the Newcastle-Ottawa scale for the assessment of the quality of nonrandomized studies in meta-analyses. Eur J Epidemiol. 2010;25(9):603-5.

8. Tan R, Pu D, Cao J, Ge H, Chang X, Ye G, et al. Prevalence of stress urinary incontinence in women with premature ovarian insufficiency. J Womens Health (Larchmt). 2018;27(12):1508-12.

9. Melo MHV, Micussi MTABC, Medeiros RD, Cobucci RN, Maranhão TMO, Gonçalves AK. Pelvic floor muscle thickness in women with polycystic ovary syndrome. Clin Exp Obstet Gynecol. 2018;25(6):813-6.

10. Taghavi SA, Bazarganipour F, Allan H, Khashavi Z, Reisi N, Dosha N, et al. Pelvic floor dysfunction and polycystic ovary syndrome. Hum Fertil (Camb). 2017;20(4):262-7.

11. Sahinkanat T, Ozturk E, Ozkan Y, Coskun A, Ekerbicer $H$. The relationship between serum testosterone levels and bladder storage symptoms in a female population with polycystic ovary syndrome. Arch Gynecol Obstet. 2011;284(4):879-84.

12. Micussi MT, Freitas RP, Varella L, Soares EM, Lemos TM, Maranhão TM Relationship between pelvic floor muscle and hormone levels in polycystic ovary syndrome. Neurourol Urodyn. 2016;35(7):780-5.

13. Vassimon FI, Ferreira CH, Martins WP, Ferriani RA, Batista RL, Bo K. Surface electromyography and ultrasound evaluation of pelvic floor muscles in hyperandrogenic women. Int Urogynecol J. 2016;27(4):587-91.

14. Antonio FI, Bo K, Ferriani RA, Sá MF, Sá Rosa e Silva AC, Ferreira CH. Pelvic floor muscle strength and urinary incontinence in hyperandrogenic women with polycystic ovary syndrome. Int Urogynecol J. 2013;24(10):1709-14.

15. Montezuma T, Antonio FI, Rosa e Silva AC, Sá MF, Ferriani RA, Ferreira CH.
Assessment of symptoms of urinary incontinence in women with polycystic ovary syndrome. Clinics (Sao Paulo). 2011;66(11):1911-5.

16. Fante IF, Machado HC, Juliato CRT, Benetti-Pinto CL, Brito LGO. Pelvic floor disorders in women with premature ovarian insufficiency: a cross-sectional study. Menopause. 2020;27(4):450-8.

17. Clark AL, Slayden OD, Hettrich K, Brenner RM. Estrogen increases collagen I and III mRNA expression in the pelvic support tissues of the rhesus macaque. Am J Obstet Gynecol. 2005;192(5):1523-9.

18. Velders $M$, Schleipen $B$, Fritzemeier KH, Zierau O, Diel P. Selective estrogen receptor- $\beta$ activation stimulates skeletal muscle growth and regeneration. Faseb |. 2012;26(5):1909-20.

19. Goldstein I. Recognizing and treating urogenital atrophy in postmenopausal women. J Womens Health (Larchmt). 2010;19(3):425-32.

20. Cody ID, Jacobs ML, Richardson K, Moehrer B, Hextall A. Oestrogen therapy for urinary incontinence in post-menopausal women. Cochrane Database Syst Rev. 2012;10(10):CD001405

21. Robinson D, Toozs-Hobson $P$, Cardozo L. The effect of hormones on the lower urinary tract. Menopause Int. 2013;19(4):155-62.

22. Vural B, Caliskan E, Doger E, Ercin C. Uterine prolapse in a young nulligravida with scleroderma and premature ovarian failure. Int Urogynecol | Pelvic Floor Dysfunct. 2005;16(5):415-7.

23. Lemoine S, Granier P, Tiffoche C, Rannou-Bekono F, Thieulant ML, Delamarche P. Estrogen receptor alpha mRNA in human skeletal muscles. Med Sci Sports Exerc. 2003;35(3):439-43.

24. Sinha-Hikim I, Roth SM, Lee MI, Bhasin S. Testosterone-induced muscle hypertrophy is associated with an increase in satellite cell number in healthy, young men. Am J Physiol Endocrinol Metab. 2003;285(1):E197-205.

25. Bhasin S, Calof OM, Storer TW, Lee ML, Mazer NA, Jasuja R, et al. Drug insight: testosterone and selective androgen receptor modulators as anabolic therapies for chronic illness and aging. Nat Clin Pract Endocrinol Metab. 2006;2(3):146-59.

26. Douchi T, Yamamoto S, Oki T, Maruta K, Kuwahata R, Nagata Y. Serum androgen levels and muscle mass in women with polycystic ovary syndrome. Obstet Gynecol. 1999;94(3):337-40.

27. Gozukara YM, Akalan G, Tok EC, Aytan H, Ertunc D. The improvement in pelvic floor symptoms with weight loss in obese women does not correlate with the changes in pelvic anatomy. Int Urogynecol J. 2014;25(9):1219-25.

28. Sinha-Hikim I, Taylor WE, Gonzalez-Cadavid NF, Zheng W, Bhasin S. Androgen receptor in human skeletal muscle and cultured muscle satellite cells: up-regulation by androgen treatment. J Clin Endocrinol Metab. 2004;89(10):5245-55 